\title{
A COMPARATIVE STUDY OF ACADEMIC ADVISING PRACTICE IN PUBLIC AND PRIVATE UNIVERSITIES IN NIGERIA
}

\author{
BY \\ REGINA ARUORIWO TOBI-DAVID \\ MAT. NO. 15PBD01260
}
A Dissertation Submitted to the Department of Psychology, College of Leadership and Development Studies in Partial Fulfilment of the Requirements for the Award of Masters of Arts (M.A.) Degree in Counselling Psychology.

Covenant University, Ota

June, 2018 


\section{DECLARATION}

I, Tobi-David, Aruoriwo Regina (15PBD01260) hereby do declare that this research work was carried out by me under the supervision of Dr. Adedayo Odukoya of the Department of Psychology, Covenant University, Ota. I attest that dissertation has not been presented either wholly or partly for the any of degree elsewhere. All the source of data and scholarly information used in this dissertation are duly acknowledged.

\section{Tobi-David Regina}

Signature and Date 


\section{ACCEPTANCE}

This is to attest that this dissertation is accepted in partial fulfillment of the requirement of the degree of Masters of Arts (M.A.) in Counselling Psychology in the department of Psychology, College of Leadership Development Studies, Covenant University, Ota.

Mr. Phillip John Ainwokhai

(Secretary, School of Postgraduate Studies)

Signature/Date

Professor Abiodun H. Adebayo

(Dean, School of Postgraduate Studies)

Signature/Date 


\section{CERTIFICATION}

I certify that this Study was carried out by Tobi-David, Aruoriwo Regina with matriculation number 15PBD01260 of the Department of Psychology certified by me in partial fulfillment of the award of Master of Arts (M.A.) Degree in Counselling Psychology, College of Leadership Studies, Covenant University, Ota, Ogun State, Nigeria.

Dr. Jonathan Adedayo Odukoya Supervisor Signature and Date

Dr. Gbadebo Adejumo

Head of Department

Signature and Date 


\section{DEDICATION}

This project work is dedicated to the Almighty God, Creator of Heaven and Earth, the Giver and Sustainer of life who enabled me to commence and finish this programme.

I also dedicate the work to my caring and supportive husband, Mr. Oluwatobi David for his understanding and endurance throughout the period of this programme. 


\section{ACKNOWLEDGEMENT}

First and foremost, I acknowledge my heavenly father, God Almighty for His loving kindness, mercies and divine enablement throughout the period of this programme.

I acknowledge the Chancellor, Dr. David Oyedepo, my supervisor, Dr. Jonathan Adedayo Odukoya for his guidance and valuable contributions.

I also wish to acknowledge my dearest husband, Mr. Oluwatobi David for being there for me all the time, his moral and financial support. My gratitude goes to my lovely children, Oluwadarasimi, Temilayo and Yondafoluwa for their prayers and support.

I also want to acknowledge all the faculty in the Department of Psychology, the HOD, Dr. Gbadebo Adejumo, Prof. Aize Obayan, Prof. Olujide Adekeye, Prof. Gesinde, Dr. Adeusi, Dr. Elegbeye, Dr. Olowokere, Dr. Ben Agoha, Dr. David Igbokwe and Dr. Evuboma for their support and assistance. 
I wish also to specially thank my brothers and sisters, Chief James Omovre, David Omovre, Victor Eruewo, Mrs. Racheal Osibi, and Helen Itoje for their support.

I wish to acknowledge my Boss the Vice-Chancellor, Prof AAA. Atayero, DVCO, Prof. Omole, Prof. Adetiba, Director, CSIS, Dr. Anake, Dean, Student Affairs, SAR-VCO, Mr. Joshua Ogaga-oghene, Mr. Samuel Akinwale and all the staff of the Vice-Chancellor's office for their support.

\title{
TABLE OF CONTENT
}

\author{
Title Page \\ i \\ Declaration \\ ii \\ Acceptance \\ iii \\ Certification \\ iv \\ Dedication \\ vi \\ Acknowledgements \\ vii \\ Table of Content \\ vii \\ List of Tables \\ ix
}


Abstract

$\mathrm{X}$

CHAPTER ONE: INTRODUCTION

1

- Background to the Study

1

- Statement of Problem

3

- Objectives

5

- Research Questions

5

- Research Hypothesis

6

- Significance of the Study

6

- Scope of the Study

6

- Operational Definition of Terms

7

CHAPTER TWO: REVIEW OF RELATED LITERATURE 8

2.1 Empirical Review of Literature on Academic Advising 8

2.2 Theories that support Academic Advising

13 
2.3 Definition and Description of Academic Advising 15

2.4 Academic Advising process 17

2.5 Models of Academic Advising 18

2.6 Developmental Advising 18

2.7 Prescriptive Advising 19

2.8 Intrusive Advising 19

2.9. Strength Based Advising 20

2.10. History of Academic Advising 20

2.11. NACADA Concept of Academic Advising 21

2.12. Organizational Model for Advising 23

2.13. The Goals and Role of the Academic Adviser 23

CHAPTER THREE: RESEARCH METHODOLOGY 26

3.1 Research Design 26

3.2 Population of the Study 26

3.3. Sample and Sampling Techniques 27

3.4. Sample Distribution 27

3.5 Instrumentation

28

3.6 Procedure for Data Collection 
3.7 Data Analysis

31

CHAPTER FOUR: DATA ANALYSIS, INTERPRETATION AND DISCUSSION OF FINDINGS

33

4.1 Results

33

4.2 Research Question One

33

4.3 Research Questions Two

34

4.4 Hypothesis Testing and Analysis of Empirical Results 35

4.5. Focused Group Discussion and Interview Results 41

4.6. Summary of Focused Group Interviews and Discussions 47

CHAPTER FIVE: SUMMARY, CONCLUSION AND RECOMMENDATIONS 48

5.1 Summary of Findings 48

5.2 Discussions

49

5.3 Recommendations 53

5.4 Limitation of Study 54

5.5 Suggestions for Further Research 55

5.6. Conclusion

55 
5.6 Contribution to Knowledge

55

References

56

Appendix

59

List of $\mathrm{f}$ Tables

60 


\section{LISTS OF TABLES}

Table 1: Sample distribution

Table 2: Faculty advisers' distribution

Table 3: Faculty by Gender distribution

Table 4: Data Analysis

32

Table 5: Students perception of the quality of Academic advising practice (Covenant University)

Table 6: Student perception of the quality of Academic advising practice (University of Lagos)

Table 7: Rating of Advisers' skills (Covenant) . .34

Table 8: Rating of Advising skills (University of Lagos) 35

Table 9: Knowledge of University requirements (Covenant. 35

Table 10: Knowledge of University requirements (University of 
Lagos) .35

Table 11: Knowledge of university's requirement for 2 universities ....................... 37

Table 12: Faculty Advisers possession of advising skills (Covenant) 37

Table 13: Faculty Advisers possession of advising skills (University of Lagos..............37

Table 14. Faculty Advisers possession of advising skills for 2 universities...................38

Table 15: Faculty Advisers possession of advising skills 39

Table 16:Impact of formal training on academic $\operatorname{advising}($ Covenant......................38

Table 17: :Impact of formal training on academic advising (University of Lagos ...........39

Table 18: Gender

difference....................................................... 40

Table 19: University type .40

Table 20: Summary of Focused group discussions and interviews .47

Abstract 
Academic advising is an important component of a university's structure that assist students to realize their potentials and fulfill their educational, career and professional goals. This study investigated academic advising practice in public and private universities in Nigeria. It sought to determine students' and faculty advisers' perception of academic advising practice. Survey research design was used. Questionnaire and focused group discussions were used to collect data. Students from two universities participated in focus group discussions of 10 students per group. Faculty advisers participated in individual in-depth interview. Random and split sampling techniques were used to select students and faculty advisers. A total of 560 undergraduate students (296 males and 264 females) and 85 faculty advisers (49 males and 36 females) completed the questionnaire to examined academic advising practice (AAP) in Nigerian universities. The data collected were analysed using regression and multi-variance to test the hypotheses while content analysis was used to explore the narratives of the focused group discussions. Some of the findings were that: Academic advising is at the developing stage and majority of the students $389(85 \%)$ were of the opinion that academic advising practice in Nigerian universities was moderate. Advisers knowledge of university's requirements $[\mathrm{F}(1,518)=91.804, \mathrm{P}<0.01]$. Faculty Advisers's skills $[\mathrm{F}(1,203)=199.984$, $\mathrm{P}<0.01)]$, and university type $(\mathrm{t}=4.76)$ all have significant impact on the academic advising practice. Gender effect was only significant in the use of advising skills $(\mathrm{t}=$ 2.088). This study concludes that Advisers' skills and knowledge are essential in academic advising practice. It was recommended that universities should establish Academic Advising centers because of its inherent benefits to students. 